\title{
Differences in Orientation Program Enrollment as a Function of Gender and Ethnicity for Community College Students
}

\author{
Ericka Landry and John R. Slate \\ Department of Educational Leadership, Sam Houston State University, Huntsville, United States \\ Email: profslate@aol.com
}

\begin{abstract}
This quantitative study was conducted to determine the degree to which participation in and completion of orientation programs or courses were related to student achievement as a function of gender and ethnicity (i.e., Black, White, and Hispanic) measured by the Community College Survey of Student Engagement. Using archival data, over 77,000 community college students were surveyed. Findings were that participation in the orientation programs and courses were statistically significantly related to student GPAs, for Black students and for White students, but not for Hispanic male students. These findings may provide higher education institutions, policymakers, and legislators with empirical data to assist with decision-making regarding support services for this group of students.
\end{abstract}

Keywords: Transition seminars, first-year experience seminars, student success courses, orientation programs, and orientation courses abstract

\section{Introduction}

Since the late 1800s, unique seminars were developed to assist students with transitions into higher education institutions. These transitional seminars were academic and social in nature, and have been referred to as, transition seminars, first-year experience seminars, student success courses, orientation programs, orientation courses, and study skills courses. One of the more prominent authorities on the transition seminars is Gardner, at the University of South Carolina's National Resource Center for The First-Year Experience which was established in 1988. Using 3-year recurring cycles, the National Resource Center conducts national surveys of first-year seminars. The seminar's goals are to enhance the social and academic integration of first-year college students (Barefoot, Griffin, \& Koch, 2012). Based on a National Resource Center 2013 report, 3,753 first-year experience surveys were distributed to postsecondary institutions, and 896 surveys were completed (a 24\% response rate), 804 institutions responding a first-year course was offered at their institution. Highlighted in the following paragraphs are studies related to these courses.

\section{$1.1 \quad$ Purpose}

The purpose of this quantitative study was to determine the degree to which participation in and completion of a student success course was related to student achievement (overall GPA). Examined in this study was the orientation program participation of Black, White, and Hispanic community college students using archival data from the CCSSE. Additionally, student achievement was measured as overall GPA outcomes (i.e., highly successful, successful, moderately successful, and not successful).

\section{Background}

Schnell and Doetkott (2003) analyzed the retention rates of first-year students who enrolled in a first year seminar. These students were matched to a comparison group over a period of four years. Retention rates were statistically significantly higher for students who participated in the first-year seminar group than for students who did not participate in the first-year seminar group. Statistically significant differences were present in each of the four years of the study.

The potential relationship between completing orientation courses and student retention measures has 
not been well addressed at the community college level. Derby and Smith (2004) examined the relationship between taking an orientation course and student (a) success in obtaining a degree within two years, (b) drop-out, (c) re-enrollment after short breaks - stop-outs, and (d) persistence. Each student retention measure revealed statistically significant relationships. Of the students who took the orientation course, a higher percentage obtained their degrees than students who did not take the orientation course. With regard to drop-out rates, students who took the orientation course were less likely to drop out than were those students who did not take the course. Students who were considered stop-outs (i.e., leaving college and returning within one to three semesters) tended to re-enroll after one, two, or three semesters break. Regarding persistence, students who took the orientation course were more likely to persist over time (Derby \& Smith, 2004). As such, these researchers concluded that the orientation courses were beneficial in increasing student retention and persistence.

Traditionally, students required to take developmental courses are often encouraged or mandated to take life skills courses to increase academic success. The degree to which taking and successfully completing a life skills course affected student academic achievement was investigated by the Florida Department of Education (2006). In this study, archival data were analyzed from Florida Community College System Student Data Base and the State University System Data Course Files. The sample was comprised of 36,123 first-time-in-college students who had college placement scores. The two cohorts consisted of students who took and successfully completed a student life skills course and those students who did not successfully complete the course. The cohorts were followed five years, from 1999-2000 through 2003-2004, to allow time for outcomes to be successfully measured. Each year, the student life skills cohort was more successful than the cohort of students who did not take the student life skills course (Florida Department of Education, 2006). After five years, only $20 \%$ of the no-n-student life skills cohort were still enrolled compared to $40 \%$ of the student life skills cohort. The data were also examined by race/ethnicity of the three largest cohort groups (i.e., White, Hispanic, and Black). Of these three groups, the largest impact was documented for Black students. Approximately two-fifths of Black students in the student life skills group were still enrolled after five years compared to only one-fifth of the non-student life skills group (Florida Department of Education, 2006).

In a later study, Mills (2010) examined the relationship between participation in student success courses and student engagement based on the Community College Survey of Student Engagement (CCSSE) data. Data were collected from four large community colleges of an Urban Community College District for the 2005 through the 2007 academic school years. In this study, all colleges required entering students with fewer than 15 credit hours to enroll in a student success course. Linear regression models were used to determine the relationship between student success course participation and the CCSSE engagement construct data. The resulting engagement changes for student participation ranged from $5 \%$ to $21 \%$, whereas, engagement changes for nonparticipants ranged from $3 \%$ to $21 \%$. Therefore, "no single engagement construct was statistically related to student success course participation in all 5 samples" (Mills, 2010, p. 21). One implication was that additional analyses were needed to assess patterns among students of various races, ages, and enrollment levels. Finally, Mills (2010) concluded that additional research would be beneficial to determine if colleges and universities should continue requiring new students to enroll in these student success courses.

Clark and Cundiff (2011) attempted to determine the effectiveness of first-year college experience courses on first-year GPAs. In their study, they analyzed data on 109 first-year university students enrolled in the first year experience course compared to 326 students from the same university who did not enroll in the first year experience course. In contrast to findings of prior studies, Clark and Cundiff (2011) indicated that students who took the student success course did not have higher GPAs than students who did not take the course after their first year. Given the limited results in their study, they recommended a more formative approach to evaluation to determine what aspects of the program are beneficial. Similar to Mills, one implication was that college administrators designated the student success course as an elective, thus, not making it mandatory as many colleges are requiring (Clark \& Cundiff, 2011; Mills, 2010). Due to decreasing college persistence rates, Cho and Karp (2013) examined the relationship between student success course completion and the student's persistence to the second year of college. They suggested that students who completed a student success course were more likely to persist, compared to the students who did not complete a student success course. Cho and Karp (2013) concluded that strong positive links were associated with students completing success courses during their first semester and short-term outcomes of second year persistence. 
Journal of Advances in Education Research, Vol. 3, No. 2, May 2018

Windham, Rehfuss, Williams, Pugh, and Tincher-Ladner (2014) investigated the influence of study skills course (also known as the student success course) enrollment at a community college in the Southeast. Approximately 329 first time, full-time freshmen who enrolled in the study skills course in the fall of 2008, 2009, and 2010 were the samples for the study. Windham et al. (2014) indicated that $64 \%$ of students enrolled in the success courses had increased retention rates compared to their counterparts. Students who were not enrolled in the success course were $67 \%$ less likely to be retained. Windham et al. (2014) concluded that participation in the student success courses could potentially increase student retention. Accordingly, value-added benefits were a result of taking student success courses in community colleges. Studies have been conducted to determine if graduation rates are influenced by successfully completing student success courses. Tucker and Shidfar (2014) posited that those instructors teaching life skills courses were confident the courses were beneficial; however, others with a more negative view claimed that these courses "cannot be justified with anecdotal stories" (Tucker \& Shidfar, 2014, p. 75). In the Tucker and Shidfar (2014) study, seven different life skill classes at Santa Fe College were identified. Three cohorts were present: (a) students who had not been enrolled in a life skills class at Santa Fe College, (b) students who had completed one life skills class at Santa Fe College, and (c) students who had completed two or more life skill classes at Santa Fe College. In fall 2008, 2,135 Santa Fe College students were followed for five years. The graduation rates of cohorts who successfully completed the classes were much higher than for those students who did not complete the classes. Students without the life skills class had a graduation rate of $32 \%$, students with one class had a graduation rate of $41 \%$, and students with two or more classes had a graduation rate of $55 \%$ (Tucker \& Shidfar, 2014)

\subsection{Significance of the Study}

Limited research has been conducted on orientation courses at the community college level (Barefoot, 2000; Zeidenberg, Jenkins, \& Calcagno, 2007); therefore, a major deficit exists in examining orientation programs/courses at the community college level. Although these orientation courses are prevalent in community colleges, minimal researchers have addressed their effectiveness. By examining the relationship between participation in orientation programs/courses and GPA at the community college level, this research deficit will in some small measure be addressed. Equally as important is that this study would contribute to the literature as well as provide vital information to college administrators and personnel, which can prove to be effective for student success. Additionally, the findings may provide higher education institutions, policymakers, and legislators with empirical data to assist with decision-making for future years.

In previous years, interest in retention and persistence rates has increased substantially (Schnell \& Doetkott, 2003). Major concerns have grown at many colleges and universities. First-year seminars, or orientation programs/courses, were designed to address these concerns. According to National Center for Education Statistics (2015), in fall 2013, 10.5 million undergraduate students were enrolled in 4-year institutions, whereas, 7 million were enrolled in 2-year institutions. At the 4-year institutions, approximately $77 \%$ attended full-time. On the other hand, only $41 \%$ attended full-time at the 2-year institutions. With the large population of 2-year students, college administrators and stakeholders need to be aware of the importance of orientation programs and courses they offer. An abundance of literature exists with regard to these courses being offered. However, literature is scarce regarding the degree to which these courses are effective at the community college level.

\section{$2.2 \quad$ Research Questions}

The overarching research question that was addressed in this investigation was: What is the effect of an orientation program/course on student GPA by gender and ethnicity? Sub-questions under this overarching research question were: (a) What is the effect of an orientation program/course on student GPA for Black males?; (b) What is the effect of an orientation program/course on student GPA for Black females?; (c) What is the effect of an orientation program/course on student GPA for White males?; (d) What is the effect of an orientation program/course on student GPA for White females?; (e) What is the effect of an orientation program/course on student GPA for Hispanic males?; and (f) What is the effect of an orientation program/course on student GPA for Hispanic females? We would have 
preferred to have had a research question about Asian students, however, their sample size in the dataset that we were provided was not large enough to conduct statistical analyses.

\section{$3 \quad$ Method}

\subsection{Participants}

For the purposes of this study, archival data were used. Participants in this study were community college students who completed the Community College Survey of Student Engagement (CCSSE) in the 2014 academic year. The total population of cases downloaded from (CCSSE) dataset was 108,509 students; however, some of the data were not relevant for purposes of this investigation and, therefore, were not analyzed. The final participant count was approximately 77,000.

In this study, the sample characteristics analyzed were gender and ethnicity (i.e., Black, White, and Hispanic). The independent variable present in this investigation was orientation course enrollment, in which two groups of students were present: (a) students who participated in the orientation courses and (b) students who did not participate in orientation courses. The dependent variable used in all of the analyses was student overall GPA which was measured by successful completion (i.e., highly successful $=\mathrm{A}$, successful = A- to B, moderately successful = B- to C, and not successful = C- and below) of the orientation course.

\subsection{Instrumentation and Procedures}

Established in 2001, the CCSSE was used to provide information to community colleges. Based on Mills (2010), the CCSSE is a national survey in which institutional processes and student behaviors that are associated with community college student learning and retention are explored. The survey instrument known as the Community College Student Report (CCSR) was developed to spotlight "institutional practices and student behaviors that promote student engagement" (McClenney, Marti, \& Adkins, 2002, p. 1). The more actively engaged students are, the likelihood of academic achievement success increases (CCCSSE, 2015). Each year, the CCCSSE presents results of these annual surveys. Five national benchmarks of effective educational practices were introduced. The five benchmarks are (a) active and collaborative learning, (b) student effort, (c) academic challenge, (d) student-faculty interaction, and (e) support for learners.

The CCSSE administrator was contacted to request data sets for first-year students from Texas community colleges. Once approved, the administrator emailed the data, which was then imported into the Statistical Package for Social Sciences (SPSS) software program. After the CCSSE data file was converted into a SPSS data file, relevant variables were labeled and used in this investigation, specifically item 8h. Survey item 8h, orientation program or course, was used as the independent variable. Because student data were reported directly from the CCSR, minimal errors in the data are assumed to be present.

\section{$4 \quad$ Results}

To determine whether a difference was present in student success as a function of their orientation program/course enrollment, Pearson chi-square analyses were conducted separately by gender within each of three ethnic/racial groups. This statistical procedure was viewed as the optimal statistical procedure to use because frequency data were present for orientation program/course enrollment (i.e., had been enrolled or had not been enrolled) and for student success (i.e., GPA groupings). Thus, chisquares are the statistical procedure of choice when both variables are categorical (Slate \& RojasLeBouef, 2011). With the large sample size, the available sample size per cell was more than five. Therefore, the assumptions for utilizing a chi-square were met.

For the first research sub-question in which the focus was placed on differences in GPAs as a function of orientation program enrollment for Black males, the result was statistically significant, $\chi^{2}(3)=10.36$, $p<.001$. The effect size for this finding, Cramer's V, was below small, .05 (Cohen, 1988). As shown in 
Table 1, Black males who participated in orientation programs, were about twice as likely to be successful than were Black males who did not participate in orientation programs.

Table 1. Frequencies and percentages of student GPAs as a function of orientation program/course enrollment for black male and female students

\begin{tabular}{l|l|l|l}
\hline Gender, Ethnicity/Race, and GPA Status & $n$ & $\%$ Not Enrolled & \% Enrolled \\
\hline Black Males & 3,935 & & \\
\hline Highly Successful & 304 & $7.6 \%$ & $7.9 \%$ \\
\hline Successful & 1,872 & $46.2 \%$ & $49.2 \%$ \\
\hline Moderately Successful & 1,607 & $41.6 \%$ & $40.0 \%$ \\
\hline Not Successful & 152 & $4.7 \%$ & $2.9 \%$ \\
\hline Black Females & 5,977 & & \\
\hline Highly Successful & 487 & $8.0 \%$ & $8.3 \%$ \\
\hline Successful & 3,061 & $50.0 \%$ & $51.6 \%$ \\
\hline Moderately Successful & 2,215 & $37.0 \%$ & $37.1 \%$ \\
\hline Not Successful & 214 & $4.3 \%$ & $2.9 \%$ \\
\hline
\end{tabular}

Regarding the second research sub-question on differences in GPAs as a function of orientation program enrollment for Black females, the result was statistically significant, $\chi^{2}(3)=8.63, p<.001$. The effect size for this finding, Cramer's V, was below small, .05 (Cohen, 1988). Similar to Black males, Black females who participated in orientation programs were about 1.5 times more likely to be successful than were Black females who did not participate in orientation programs. Readers are referred to Table 1 for the data analysis.

A statistically significant difference was yielded in GPAs for White males by orientation program enrollment, $\chi^{2}(3)=14.85, p<.001$. The effect size for this finding, Cramer's V, was below small, .03 (Cohen, 1988). As indicated in Table 2, White males who participated in the orientation programs were about 1.5 times more likely to succeed than White males who did not participate in the orientation programs.

Table 2. Frequencies and percentages of student GPAs as a function of orientation program/course enrollment for white male and female students

\begin{tabular}{c|c|c|c}
\hline Gender, Ethnicity/Race, and GPA Status & $n$ & $\%$ Not Enrolled & $\%$ Enrolled \\
\hline White Males & 23,541 & & \\
\hline Highly Successful & 4,101 & $17.8 \%$ & $16.8 \%$ \\
\hline Successful & 13,266 & $56.2 \%$ & $56.7 \%$ \\
\hline Moderately Successful & 5,728 & $24.0 \%$ & $25.0 \%$ \\
\hline Not Successful & 446 & $2.1 \%$ & $1.5 \%$ \\
\hline White Females & 30,725 & & \\
\hline Highly Successful & 6,373 & $22.0 \%$ & $18.9 \%$ \\
\hline Successful & 17,799 & $56.8 \%$ & $59.6 \%$ \\
\hline Moderately Successful & 6,178 & $19.9 \%$ & $20.4 \%$ \\
\hline Not Successful & 375 & $1.3 \%$ & $1.1 \%$ \\
\hline
\end{tabular}

For the fourth research sub-question, concerning GPAs as a function of orientation program enrollment for White females, the result was statistically significant, $\chi^{2}(3)=45.43, p<.001$. The effect size for this finding, Cramer's V, was below small, .04 (Cohen, 1988). Interestingly, White females who did not participate in orientation programs, were about 3 times more successful compared to White females who did participate in orientation programs. Readers are directed to Table 2 for the descriptive statistics on the data analysis. 
With regard to the fifth research sub-question on GPAs as a function of orientation program enrollment for Hispanic males, a statistically significant difference was not present, $\chi^{2}(3)=1.45$, $p=695$. Hispanic males had similar GPAs regardless of whether or not they had enrolled in an orientation program at their community college. Delineated in Table 3 are the descriptive statistics for this analysis.

Table 3. Frequencies and percentages of student GPAs as a function of orientation program/course enrollment for hispanic male and female students

\begin{tabular}{l|l|l|l}
\hline Gender, Ethnicity/Race, and GPA Status & $n$ & $\%$ Not Enrolled & $\%$ Enrolled \\
\hline Hispanic Males & 5,273 & & \\
\hline Highly Successful & 530 & $10.4 \%$ & $9.4 \%$ \\
\hline Successful & 2,868 & $54.0 \%$ & 55.0 \\
\hline Moderately Successful & 1,711 & $32.5 \%$ & $32.4 \%$ \\
\hline Not Successful & 174 & $3.1 \%$ & $3.1 \%$ \\
\hline Hispanic Females & 7,372 & & \\
\hline Highly Successful & 779 & $11.0 \%$ & $10.0 \%$ \\
\hline Successful & 4,128 & $54.5 \%$ & $58.0 \%$ \\
\hline Moderately Successful & 2,273 & $31.4 \%$ & $30.0 \%$ \\
\hline Not Successful & 192 & $3.1 \%$ & $1.9 \%$ \\
\hline
\end{tabular}

Concerning the final research sub-question on GPAs as a function of orientation program enrollment for Hispanic females, the result was statistically significant, $\chi^{2}(3)=15.80, p<.001$. The effect size for this finding, Cramer's V, was below small, .05 (Cohen, 1988). Hispanic females who participated in orientation programs, were 3.5 times more likely to be successful than were Hispanic females who did not participate in orientation programs. Table 3 contains the descriptive statistics for this analysis.

\section{Discussion}

Results from this empirical investigation add to the current literature (Cho \& Karp, 2013; Clark \& Cundiff, 2011; Mills, 2010) on orientation programs or courses by examining student outcomes by gender within three major ethnic/racial groups of community college students. Based on CCSSE reports, student success courses are considered as high-impact practices, which increase student engagement. These courses in which new students are usually the focus help students overcome obstacles to success and orient them to the college environment. An implicit goal of these courses is ultimately to improve completion and graduation rates (CCSSE, 2015). A wide variety of other support services (e.g., advising, financial aid, guest lecturers, and other campus representatives) can be incorporated into the student success courses. Providing these additional support systems may ensure students are better oriented during their early college years.

In analyzing CCSSE data, five of the six analyses yielded statistically significant differences as a function of orientation program enrollment. Only for Hispanic male students was orientation program enrollment not related to their GPAs. In four of the five statistically significant results, students who had completed an orientation program or course had statistically significantly higher GPAs than did their peers who had not completed an orientation program or course. The one conflicting result was yielded for White females who had statistically significantly higher GPAs when they did not complete an orientation program or course. This result merits further investigation.

The existing research literature was supported with regard to the findings in this study (Derby \& Smith, 2004; Schnell \& Doetkott, 2003). Enrolling and successfully completing orientation programs and courses was positively related to student GPA. Based on these findings, the need for additional research at the community college level is warranted. Focus should be placed on Hispanic male students and various support programs to assist them with smooth college transition.

Transition to college is multi-faceted and somewhat complex for community college students. Colleges should consider conducting in depth program evaluations to ensure appropriate supports are in place for 
these students. Future research should be considered regarding various course offerings, which could help increase retention and persistence rates over time.

\section{References}

1. Barefoot, B. O. (2000). The first year experience: Are we making it any better? About Campus, 4(6), 12-18.

2. Barefoot, B. O., Griffin, B. Q., \& Koch, A. K. (2012). Enhancing student success and retention through undergraduate education: A national study. Retrieved from John Gardner Institute for Excellence in Undergraduate Education website: http://www.jngi.org/wordpress/wpcontent/uploads/2012/04/JNGInational_survey_web.pdf

3. Cho, S., \& Karp, M. M. (2013). Student success courses in the community college: Early enrollment and educational outcomes. Community College Review, 41(1), 86-103. doi:10.1177/0091552112472227.

4. Clark, M. H., \& Cundiff, N. L. (2011). Assessing the effectiveness of a college freshman seminar using propensity score adjustments. Research in Higher Education, 52(6), 616-639. doi:10.1007/s11162-010-9208-x.

5. Cohen, J. (1988). Statistical power analysis for the behavioral sciences (2nd ed.). Hillsdale, NJ: Lawrence Erlbaum.

6. Center for Community College Student Engagement. (2015). 2015 Cohort findings. Retrieved from http://www.ccsse.org/center/

7. Derby, D. C., \& Smith, T. (2004). An orientation course and community college retention. Community College Journal of Research and Practice, 28, 763-773. doi:10.1080/10668920390254771.

8. Florida Department of Education. (2006). Taking student life skills course increases academic success. Data Trend \#31. Tallahassee, FL: Author. Retrieved from http://www.fldoe.org/core/fileparse.php/3/urlt/dt31.pdf

9. McClenney, K., Marti, C. N., \& Adkins, C. (2002). Student engagement and student outcomes: Key findings from CCSSE validation research. Community College Survey of Student Engagement. Retrieved from https://www.ccsse.org/aboutsurvey/docs/CCSSE\%20Validation\%20Summary.pdf.

10.Mills, M. T. (2010) Tools of engagement: Success course influence on student engagement. Journal of The FirstYear Experience \& Students in Transition, 22(2), 9-31.

11.National Center for Education Statistics. (2015, May). Characteristics of postsecondary students. U.S. Department of Education. Retrieved from http://nces.ed.gov/programs/coe/indicator_csb.asp.

12.National Resource Center. First-year experience and students in transition. (2013). 2012-2013 National survey of first-year seminars. Retrieved from http://www.sc.edu/fye/research/surveys/survey_instruments/pdf/Executive_Summaries_2013_National_Surve y__FirstYearSeminars.pdf

13.Schnell, C. A., \& Doetkott, C. D. (2003). First year seminars produce long-term impact. Journal of College Student Retention, 4(4), 377-391.

14.Slate, J. R., \& Rojas-LeBouef, A. (2011). Calculating basic statistical procedures in SPSS: A self-help and practical guide to preparing theses, dissertations, and manuscripts. Ypsilanti, MI: NCPEA Press.

15.Tucker, B. N., \& Shidfar, P. (2014). A study of the impact of SLS, skills classes, on graduation rates. Education Practice and Innovation, 1(4), 75-78. doi:10.15764/epi.2014.04008

16.Windham, M. H., Rehfuss, M. C., Williams, C. R., Pugh, J. V., \& Tincher-Ladner, L. (2014). Retention of firstyear community college students, Community College Journal of Research and Practice, 38(5), 466-477. doi:10.1080/10668926.2012.743867.

17.Zeidenberg, M., Jenkins, D., \& Calcagno, J. C. (2007). Do student success courses actually help community college students succeed? (CCRC Brief No. 36). New York, NY: Columbia University, Teachers College, Community College Research Center. 